\title{
With or without you: does partner satisfaction and partner-directed violence influence the presence of a partner on women's Facebook cover profile photographs?
}

\author{
Pavol Prokop ${ }^{1 *}$, Natália Morvayová ${ }^{2}$ and Peter Fedor ${ }^{3}$ \\ 1 Department of Biology, Faculty of Education, Trnava University, Priemyselná 4, 91843 Trnava, (Slovakia). \\ 2 Department of Psychology, Faculty of Social Science and Health Service, Constantine the Philosopher University in Nitra, Kraskova 601/1, 94974 (Nitra). \\ 3 Department of Environmental Ecology, Comenius University, Mlynská dolina B2, 84215 Bratislava, (Slovakia).
}

\begin{abstract}
Título: Contigo o sin ti: ¿la satisfacción de pareja y la violencia dirigida a la pareja influyen en la presencia de la pareja en la fotografía del perfil en Facebook de una mujer?

Resumen: las redes sociales (RS) proporcionan nuevas oportunidades para la auto-presentación on line de millones de usuarios. La fotografía del perfil (FDP), junto con información escrita sobre estado civil es un componente central de la auto-presentación en línea, a pesar de su relación con las relaciones románticas reales no son claras. Se investigaron las relaciones en tre la presencia de una pareja romántica actual en el FDP y el estado de la relación y satisfacción de la pareja, la violencia dirigida a la pareja y la competetividad intrasexual de las mujeres con sus iguales. Un total de $28 \%$ de 158 mujeres con un perfil en Facebook involucradas en una relación romántica tenían a sus parejas sentimentales en su FDP. Como se predijo, las mujeres con sus parejas en su FDP estaban más satisfechas con su relación romántica que otras. Por otra parte, las mujeres que no tienen su pareja en su FDP tendían a ocultar o mentir sobre su estado civil lo que sugiere que esto puede ser una estrategia para atraer a otra pareja potencial. Las hipótesis sobre violencia y competencia intrasexual no fueron confirmadas. En general, el FDP y un status de relación que se muestra sinceramente es una expresión de satisfacción en la relación de pareja de las mujeres.

Palabras clave: Facebook; satisfacción de pareja; retención de pareja; fotografía de perfil; estado civil; insultos dirigidos a la pareja; competitividad intrasexual.
\end{abstract}

\section{Introduction}

Social network sites (SNSs) such as Facebook attract the attention of approximately $75 \%$ of young people (ages 18 29) (Lenhart, 2010) and, in contrast to face to face communication, provide new cyberspace for interaction between users (Kizza, 2010). Each Facebook user can share posts, videos or various links with "friends" which primarily creates a connection between people known from offline contexts (Muise, Christofides, \& Desmarais, 2009; Reich et al., 2012). By creating a Facebook profile, users present themselves to others both visually (by uploading a profile photograph) and verbally (by providing private information, such as relationship status, personal interests, etc.) (Taraszow et al., 2010; Zhao, Grasmuck, \& Martin, 2008). Active use of SNSs can be viewed as a double-edged sword; it can enhance positive social outcomes on the one hand (Bucher, 2013; Subrahmanyam et al., 2008; Valkenburg \& Peter, 2007), and aggression on the other hand (Estevez et al., 2010; Schenk \& Fremouw, 2012; Slonje, Smith, \& Frisen, 2013).

Personal profiles on Facebook express the actual influence of the social environment (Zhao et al., 2008). Among

* Dirección para correspondencia [Correspondence address]: Pavol Prokop Department of Biology, Faculty of Education, Trnava University, Priemyselná 4, 91843 Trnava, (Slovakia).

E-mail: pavol.prokop@truni.sk
Abstract: Social network sites (SNSs) provide new opportunities for online self-presentation of millions of users. The cover profile photograph (CPP) along with written information regarding relationship status is a central component of online self-presentation, although their associations with actual romantic relationships are not clear. We investigated relationships between the presence of a current romantic partner on the CPP and the displayed relationship status and partner satisfaction, partner-directed violence and women's intrasexual competition with peers. A total of $28 \%$ of the 158 women with a Facebook profile and being involved in a romantic relationship had their romantic partners on their CPP. As predicted, women with their partners on the CPP were more satisfied with their romantic relationship than others. Furthermore, women who did not have their partner on the CPP tended to conceal or lie in their displayed mating status suggesting that this may be a strategy how to attract another potential mate. The partner-directed violence and intrasexual competition hypotheses were not supported. Overall, the CPP and an honestly displayed relationship status is an expression of relationship satisfaction amongst women.

Key words: Facebook; partner satisfaction; mate retention; profile photograph; relationship status; partner-directed insults; intrasexual competitiveness.

the explicitly presented written expressions such as information about age, gender or relationship status (Raad, Chbeir, \& Dipanda, 2013), the profile photographs assume a prominent position in an online presentation which is critical for engaging in interpersonal relations (Hancock \& Toma, 2009; Wang et al., 2010). Those users whose profiles contain photographs are contacted about seven times more often than users lacking photographs (Humphreys, 2004) which is probably the case why a vast majority of students, particularly females (Mesch \& Beker, 2010) reported that they posted a photo of themselves on Facebook (Hum et al., 2011; Young \& Quan-Haase, 2009). A brief look on someone's photograph reveals surprisingly significant information about someone, such as interest in children (Roney et al., 2006), physical strength (Sell et al., 2009), certain personality traits (Little \& Perrett, 2007), or interest in casual sex (Elliot \& Pazda, 2012) reinforcing the importance of profile photographs in establishing interpersonal relationships.

Women are sometimes targets of partner-directed violence (Arriaga \& Oskamp, 1999) which can have negative physical and/or psychological consequences (e.g., Chowdhary \& Patel, 2008; Zakar et al., 2013; Zweig et al., 1999). Early detection and prevention of partner-directed violence may be beneficial in order to prevent more serious injuries (Daniel \& Milligan, 2013; Gladstein, Slater Rusonis, \& Heald, 1992; Yut-Lin \& Othman, 2008). Self-presentation through cover profile photographs has not as yet been considered 
within the context of partner-directed violence. Since females on SNSs are more focused on their existing network of friends rather than on anonymous virtual friends (Tufekci, 2008), with an attempt to present themselves on SNSs authentically (Haferkamp, \& Krämer, 2010; Stern \& Taylor, 2007) and are more open and expressive than in offline selfpresentations (Foon Hew, 2011; Mesch \& Beker, 2010; see also Nguyen, Bin, \& Campbell, 2012 for a critical review), we suggest that the detection of male-directed violence can be extended to the cover profile photograph (CPP).

In this study, we investigated whether the Facebook CPP in women expresses the strength of their actual romantic relationship. Easy detection of a partner-directed insult would be effectively used in programmes focused on prevention of intimate partner violence. We hypothesized that women might present their actual romantic partners on the CPP to express their positive satisfaction (Hypothesis 1). This hypothesis can be also extended to the honesty of the information regarding relationship status: (satisfied) women with a partner on their cover profile photograph should present themselves as being involved in a romantic relationship more than dissatisfied women. Another mechanism of partner presence on the CPP can be that the woman is a target of partner-directed violence and mate guarding, thus, she is forced to depict him on her CPP (Hypothesis 2). Alternatively, presenting a current romantic partner on the CPP may be influenced by intrasexual competition between women (Fisher, 2004; Vaillancourt 2005). Women, similar to men, compete for mates (e.g., Campbell, 2004; Fink et al., 2014; Fisher, 2004) obviously by derogating rival women (Vaillancourt \& Sharma 2011). If the woman is more competitive with her peers, she may present her partner on her CPP in order to visualize both his and her partnership status (Hypothesis 3). This may increase her social status among her peers (La Greca \& Harrison, 2005) and/or reduce mate poaching (Schmitt \& Buss, 2001).

\section{Methods}

\section{Participants}

The study was conducted between May and September 2013. Participants were recruited from two Slovak universities. A total of 400 females (200 per each university) were contacted via e-mail and asked to voluntarily participate in an online survey. They were informed that only those who 1 . have an active Facebook profile and 2. are actually involved in a romantic relationship, are appropriate for this study. The participants were assured that the survey was completely anonymous. Apart from other items (see below), the participants in the online survey were asked for their 1. age, 2. relationship status (involved or not involved in a romantic relationship, engaged or married), 3. whether the relationship status agrees with the status published on the Facebook profile (yes/no/I do not have displayed my relationship status), 4. relationship duration (in months), 5. sexual orientation (heterosexual, bisexual or lesbian), 6. with whom they are on their CPP (alone, with a current romantic partner or others), 7. whether their CPP is individual or shared with their current romantic partner (or other possibility), and 8. how much time they spend on Facebook daily (approximately in minutes). All items in the survey were in Slovak language. With respect to the CPP, we acknowledge that Facebook users obviously have more than one profile picture (Hum et al., 2011), but we asked specifically about the current CPP which is visible at first glance. This is because we suggest that the current CPP could reflect the most recent perception of the current romantic partner more than previously used pictures which would be associated with previous partner(s) rather than with the current one.

The translation of questionnaires (below) from English to Slovak proceeds as follows: A bilingual speaker translated the English questionnaire into Slovak. A second bilingual speaker who was also expert in this field translated the English version independently from the first one. Then the two bilingual speakers consensually resolved the few resulting discrepancies between the original English questionnaire and the translated Slovak version.

\section{Measuring of partner satisfaction}

The four-item Partner Satisfaction Scale (PSS, actual Cronbach alpha $=.80)$ (Pham, Shackelford, \& Sela, 2013) was applied to investigate participants' partner satisfaction. This scale consists of four questions about their relationship satisfaction, being answered on a Likert-type scale ranging from 1 (Not at all) to 7 (Extremely): How (1) sexually satisfied, (2) emotionally satisfied, and (3) overall satisfied are you with your partner?, and (4) how committed are you to your partner? The possible range of summed scores was between 4 and 28. The summarized score of the PSS was used in the statistical analyses.

\section{Measuring of partner-directed insults}

The Partner-Directed Insults Scale (PDIS, actual Cronbach alpha $=$.91) (Goetz, Shackelford, \& Schipper, 2006) was used to evaluate both the content of the specific insults as well as the frequency with which a man uses these insults against his partner. The PDIS consists of 47 items measuring four components: Derogating Physical Attractiveness (e.g., "My partner told me I am fat"), Derogating Value as a Partner/Mental Capacity (e.g., "My partner called me a bitch"), Derogating Value as a Person (e.g., "My partner told me that nothing I do is important"), and Accusations of Sexual Infidelity (e.g., "My partner accused me of having sex with another man"). The instructions for the PDIS are as follows: "Men sometimes try to hurt their female partner's feelings by saying insulting things to them. The following list includes insulting things that a man might say to his partner. In the column labelled 'How often (Use scale),' write the number from the scale below to indicate HOW 
OFTEN your partner used each insulting thing with you." Responses are recorded using a six-point ordered-category scale with the following values: $0=$ Never, $1=$ once, $2=$ twice to 5 times, $3=6$ to 10 times, $4=11$ to 24 times, $5=$ 25 or more times. The scores for each component were calculated by summarizing the response values for each item in that component. We presented the full PDIS score by summarizing the response values (instead of presenting data for each subscale) for all items in the scale.

\section{Measuring of mate retention}

To assess partners' mate guarding behaviour, the survey included a subscale of the Mate Retention Inventory (MRI; actual Cronbach alpha $=.90$ ) (Buss, 1988) which asked how often the participant's current partner had performed 18 mate guarding acts over the last month, ranging from 0 (Never) to 3 (Often). Examples of acts include: "My partner told me that I have to stay at home rather than go out," "My partner questioned me as to what I did when he was away." The summarized score of the response values was used in the statistical analyses.

\section{Measuring of intrasexual competitiveness}

With regard to intrasexual competitiveness, we used the female version of the Buunk and Fisher's (2009) Intrasexual Competition Scale (ICS, actual Cronbach alpha $=.92$ ). The ICS consists of 12 items focused on a confrontation between same-sex individuals, particularly in the context of contact with the opposite-sex, in competitive terms under mating game scenarios. Examples of items include: "I can't stand it when I meet another woman who is more attractive than me," or "I like to be funnier and wittier than other women." Each item had 7 possible answers varying from 'not at all applicable' to 'completely applicable'. The summarized score of the response values was used in the statistical analyses.

\section{Statistical analyses}

An analysis of covariance (ANCOVA) was performed in order to examine the differences in the summarized scores of the PSS, PDIS, MRI and ICS domains between women who had their partners in their Facebook profile picture as compared with women who did not. The summarized scores of PSS, PDIS, MRI and ICS were defined as dependent variables and having a partner in the CPP (or not) and the relationship status (engaged and married) were categorical predictors. The latter variable was included as a categorical predictor because it is reasonable to suggest that a closer relationship with a partner (e.g., living together in case of married women) may be associated with more partner-directed insults and mate guarding behaviour than for dating partnerships. The participant's age, time spent on Facebook and relationship duration were defined as covariates. The domain scores were Box-Cox $(x+0.1)$ transformed in order to achieve normality. The partnership status between the participants who reported having and did not have their partners on the CPPs was carried out with the $2 \times 3$ Chi-square test. Statistical tests were performed with Statistica (v8, StatSoft 2007, Tulsa, OK, U.S.A., http://www.statsoft.com).

\section{Results}

\section{Descriptive data}

Data from 193 participants were obtained (48\% response rate), although 35 participants were removed because they did not satisfy some of the required conditions (being heterosexual, being involved in a romantic relationship, having been on a Facebook profile picture alone or with a partner, and having an individual Facebook profile [not shared with someone else]). This yielded a sample of 114 women without and 44 women with a partner on their CPP. The mean age of participants was 24 years $(\mathrm{SE}=0.33$, range: $18-41, n=158) .27$ women were married in total and the remaining 131 were engaged. A total of 120 women reported that the relationship status displayed on Facebook coincided with their actual relationship status, 29 women reported that they did not display any relationship status and there was a discrepancy between the actual and displayed relationship status for the remaining 9 women. Participants in the current sample reported moderate satisfaction with their partners (PSS domain) and low scores of scales measuring partnerdirected violence/mate guarding (PDIS and MRI) (Table 1). The mean scores for ICS suggest that women perceived themselves as moderately competitive with other women. The women in the current sample reported spending a relatively large amount of time on Facebook each day (Table 1).

Table 1. Descriptive statistics of measured domains (Partner satisfaction scale [PSS], Partner-Directed Insults Scale [PDIS], Intrasexual Competition Scale [ICS] and Mate-Retention Inventory [MRI]).

\begin{tabular}{lccccc}
\hline \multicolumn{7}{c}{ Mean } & SE & Min & Max & $n$ \\
\hline PSS & 24.46 & 0.25 & 11.00 & 28.00 & 158 \\
PDIS & 11.47 & 1.19 & 0.00 & 92.00 & 158 \\
ICS & 43.09 & 1.35 & 13.00 & 91.00 & 158 \\
MRI & 6.60 & 0.50 & 0.00 & 30.00 & 158 \\
Time on FB & 91.94 & 5.98 & 0.00 & 360.00 & 158 \\
\hline
\end{tabular}

Hypothesis 1: Women might present their current romantic partners on CPP to express their positive satisfaction.

After controlling for the participant's age, relationship length and time spent on $\mathrm{FB}$, women with a partner on the CPP scored higher in the PSS domain $(F(1,151)=4.11, p=.04$, Fig. 1) suggesting that those who had their partners on their profile picture showed a greater partner satisfaction than those who had no partners on their CPP. There was no effect on women's partnership status, or an interaction between the variables on partner satisfaction score $(F(1,151)=$ 3.41 and 1.19 , both $p>.06)$. This supports Hypothesis 1 . 
Hypothesis 2. Women are forced to depict their partners on the CPP as a result of partner-directed violence and mate guarding

After checking for the participant's age, relationship length and time spent on $\mathrm{FB}$, women with a partner on the CPP scored similarly in both PDIS and MRI than women without their partners on the $\mathrm{CPP}(F(1,151)=2.35$ and 2.0 , both $p>$ .12 , respectively). This provides no support for Hypothesis 2.

Hypothesis 3. More competitive women may present their partners on the CPP in order to visualize both his and her partnership status

After checking for the participant's age, relationship length and time spent on FB, women with partners on the CPP scored similarly in ICS than women without their partners on the CPP $(F(1,151)=0.31, p=.58)$. This provides no support for Hypothesis 3.

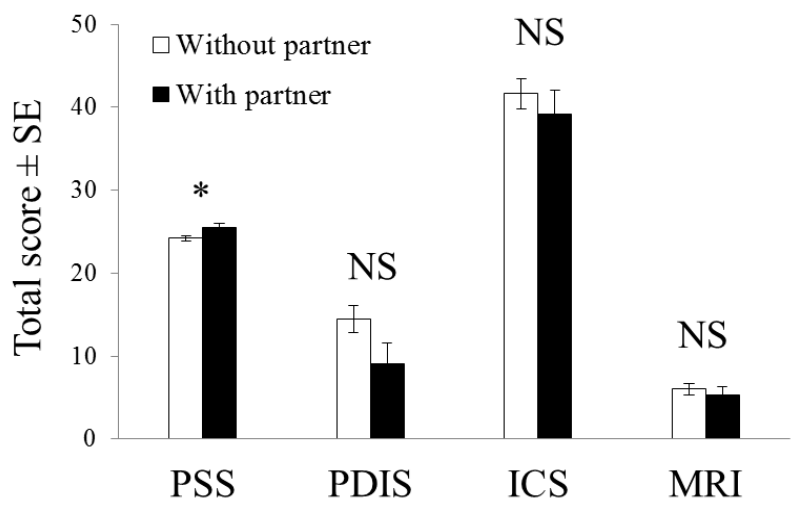

Figure 1. Differences in the total score (untransformed data) of four domains between women having and not having their partner on the profile picture. The asterisk $(*)$ denotes a significant difference between groups $(p$ $<0.05)$. NS $=$ not statistically significant.

\section{Actual and displayed relationship status}

A majority of women $(41 / 44,93 \%)$ who had their partners on the CPP reported that their actual relationship status was in agreement with the displayed relationship status on their Facebook profile while the remaining three women did not display their relationship status. However, only $69 \%$ $(79 / 114)$ of women who did not have their partners on the CPP reported a correspondence between the actual and displayed relationship status, while $23 \%(26 / 114)$ did not display their relationship status and the remaining $8 \%(9 / 114)$ lied. These differences were statistically significant (Chisquare test, $\chi^{2}=10.28, \mathrm{df}=2, p=.006$ ). Along with the previous results demonstrating that the presence of a partner on a cover profile photograph is associated with partnership satisfaction, this suggests that women more satisfied with their partners present their relationship status more honestly than their less satisfied counterparts providing further support for Hypothesis 1.

\section{Discussion}

Our primary concern in this study was the connection between the presence of a current romantic partner on the profile photograph and partnership satisfaction and/or partnerdirected violence. As far as we are aware, this is the first attempt to examine these variables through Facebook profile photographs.

According to our first hypothesis, the current romantic partner is displayed on Facebook profile pictures particularly amongst women who are more satisfied with their current romantic partners. This hypothesis received statistical support suggesting that more satisfied women display their partners in their profile pictures more than their less satisfied counterparts. This finding supports the idea that participation in SNSs positively enhances social relationships (e.g., Bucher, 2013; Subrahmanyam et al., 2008; Valkenburg \& Peter, 2007). It is also possible that the presence of a partner signals no interest in the part of a female in pursuing a new romantic relationship with someone else. Additional support for the partner satisfaction hypothesis comes from a comparison of displaying the current relationship status. While women who had their partners in their Facebook profile photograph did not lie and more than $90 \%$ of them displayed their current relationship status honestly, women without their partners in the profile picture tented to lie or conceal their relationship status. One possible explanation which is based on the above described findings is that the former group of women is more satisfied with their partners and therefore have no need to conceal their relationship statuses. In contrast, less satisfied women may conceal their relationship status which may encourage other potential men to initiate dating with them. We are not aware of any study examining this association, but deception in cyberspace does exist (Toma \& Hancock, 2010). Furthermore, if a woman presents herself as not being explicitly involved in a romantic relationship, her attractiveness for men is higher than when involvement in a romantic relationship is shown (Shackelford et al., 2004).

The partner-directed violence/mate guarding hypothesis and intrasexual competition hypothesis have not been supported because women with their partners depicted in the cover profile photograph received lower scores on the PDIS/MRI and ISC scales. Although these differences were not statistically significant, they contradict the expected results. These negative findings do not mean, however, that negative outcomes between partners cannot be detected through cyberspace. Certain researchers have actually found that jealousy between partners in cyberspace might be expressed through frequent Facebook use (Muise et al., 2009) and/or by Facebook intrusion (Elphinson \& Noller, 2011). We did not ask participants, however, how much time their partners spend on Facebook and/or how much time they spent in online communication with their partners. Furthermore, not all people use Facebook, and perhaps non-users would be more likely to be a target of partner-directed vio- 
lence. This question deserves further study. With respect to intrasexual competition, it is of interest that despite women tending to be more likely to use SNSs for comparing themselves with others (Haferkampf et al., 2012), it would seem that displaying a current social partner is not associated with intrasexual competitiveness. Perhaps the physical attractiveness of a current partner and his attitudes toward presenting himself on the profile picture of his girlfriend should be included in the analyses in further studies.

Low scores of scales measuring partner-directed violence/mate guarding (PDIS and MRI) are comparable with those published by Buss (1988), Goetz et al. (2006), or Starrat, Goetz, Shackelford and Stewart-Williams (2008) suggesting that findings observed in this study are similar with U.S. samples. As far as we are aware, however, no research investigated relationships between women's CPP and relationship

\section{References}

Arriaga, X.B., \& Oskamp, S. (1999). Violence in intimate relationships. CA: Sage.Thousand Oaks.

Bevan, J. L. (2011). A picture is worth a thousand words: A content analysis of Facebook profile photographs. Computers in Human Behavior, 27, 1828-1833. doi: 10.1016/j.chb.2011.04.003

Bucher, T. A. (2013). The friendship assemblage: Investigating programmeds on Facebook. Television \& New Media, 14, 479-493. doi: 10.1177/1527476412452800

Buss, D. A. (1988). From vigilance to violence: Tactics of mate retention in American undergraduates. Ethology and Sociobiology, 9, 291-317. doi: 10.1016/0162-3095(88)90010-6

Buss, D. M. 2011: Evolutionary Psychology. The New Science of the Mind (4th edn). Prentice Hall, New York.

Buunk, A. P., \& Fisher, M. (2009). Individual differences in intrasexual competition. Journal of Evolutionary Psychology, 7, 37-48. doi: 10.1556/JEP.7.2009.1.5

Campbell, A. (2004). Female competition: causes, constraints, content, and contexts. Journal of Sex Research, 49, 16-26. doi: $10.1080 / 00224490409552210$

Chowdhary, N., \& Patel, V. (2008). The effect of spousal violence on women's health: Findings from the Stree Arogya Shodh in Goa, India. Journal of Postgraduate Medicine, 54, 306-312. doi: 10.4103/0022-3859.43514

Daniel, M. A., \& Milligan, G. (2013). Intimate partner violence: how clinicians can be an asset to their patients. Journal of Psychosocial Nursing and Mental Health Services, 51, 22-28. doi: 10.3928/02793695-20130404-01

Elliot, A. J. \& Pazda, A. D. (2012). Dressed for sex: Red as a female sexual signal in humans. PLoS ONE, 7, e34607. doi: 10.1371/journal.pone.0034607

Elphinston, R. A., \& Noller, P. (2011). Time to Face It! Facebook Intrusion and the Implications for Romantic Jealousy and Relationship Satisfaction. Cyberpsychology, Behavior, and Social Networking, 14, 631-635. doi:10.1089/cyber.2010.0318

Estevez, A., Villardon, L., Calvete, E., Padilla, P., \& Orue, I. (2010). Adolescent victims of cyberbullying: prevalence and characteristics. Behavioral Psychology-Psicologia Conductual, 18, 73-89.

Fink, B., Klappauf, D., Brewer, G., \& Shackelford, T. K. (2014). Female physical characteristics and intra-sexual competition in women. Personality and Individual Differences, 58, 138-141. doi: 10.1016/j.paid.2013.10.015

Fisher, M. L. (2004). Female intrasexual competition decreases female facial attractiveness. Biology Letters, 271, 283-285.

Foon Hew, K. (2011). Students' and teachers' use of Facebook. Computers in Human Behavior, 27, 662-676. doi: 10.1098/rsbl.2004.0160 satisfaction or partner-directed violence in other cultures. For generalization we require a study sample represented by participants from a non-western culture and from various age groups. Perhaps research on older participants, where sexual competition decreases (Buss, 2011), may lead to different results compared with younger participants.

To conclude, this study demonstrated that the presence of a current romantic partner on a women's CPP was associated with partner satisfaction. Furthermore, partner satisfaction appears to be associated with a honest display of the current partnership status on the Facebook profile. The idea that male partners force women to display them in profile pictures or that it expresses a women's competitiveness with peers was not supported. The CPP may be a useful tool for estimating partner satisfaction amongst young women.

Gladstein, J., Slater Rusonis, E. J., \& Heald, F. P. (1992). A comparison of inner-city and upper-middle class youths' exposure to violence. Journal of Adolescent Health, 13, 275-280.

Goetz, A. A., Shackelford, T. K., \& Schipper, L. D. (2006). Adding insult to injury: Development and initial validation of the Partner-Directed Insults Scale. Violence and Victims, 21, 691-706. doi: 10.1891/vvv21i6a002

Haferkamp, N., \& Krämer, N. C. (2010). Creating a digital self. Impression management and impression formation on social networking sites. In Drotner K, Schrøder, KC, eds. Digital content creation: creativity, competence, critique. (pp. 129-146) New York: Peter Lang.

Haferkamp, N., Eimler, S. C., Papadakis, A. M., Kruck, J. M. (2012). Men are from Mars, women are from Venus? Examining gender differences in self-presentation on social networking sites. Cyberpsychology, Behavior, and Social Networking, 15, 91-98. doi: 10.1089/cyber.2011.0151

Hancock, J., \& Toma, C. (2009). Putting your best face forward: The accuracy of online dating photographs. Journal of Communication, 59, 367-386. doi: 10.1111/j.1460-2466.2009.01420.x

Hum, N. J., Chamberlin, P. E., Hambright, B. L., Portwood, A. C., Schat, A. C., \& Humphreys, L. (2004). Photographs and the presentation of self through online dating services. Paper presented at the National Communication Association, Chicago: IL.

Hum, N. J., Chamberlin, P. E., Hambright, B. L., Portwood, A. C., Schat, A. C., \& Bevan, J. L. (2011). A picture is worth a thousand words: A content analysis of Facebook profile photographs. Computers in Human Behavior, 27, 1828-1833. doi: 10.1016/j.chb.2011.04.003

Kizza, J. M. (2010). Cyberspace, Cyberethics, and Social Networking. In: Ethical and Social Issues in the Information Age Texts in Computer 2010 (4th edition) (pp 221-246). doi: 10.1007/978-1-84996-038-0_11

La Greca, A. M., \& Harrison, H. M. (2005). Adolescent peer relations, friendships, and romantic relationships: Do they predict social anxiety and depression? Journal of Clinical Child \& Adolescent Psychology, 34, 4961. doi: 10.1207/s15374424jccp3401_5

Lenhart, A., Purcell, K., Smith, A., \& Zickuhr, K. (2010). Social media and mobile internet use among teens and young adults. Pew Internet AmericanLife Project. /www.pewinternet.org/Reports/2010/SocialMedia-and-Young-Adults.aspxS (retrieved 13.11.13).

Little, A., \& Perrett, D. (2007). Using composite images to assess accuracy in personality attribution to faces. British Journal of Psychology, 98, 111126. doi: 10.1348/000712606X109648

Mesch, G. S., Beker, G. (2010). Are norms of disclosure of online and offline personal information associated with the disclosure of personal information online? Human Communication Research, 36, 570-592. doi: 10.1111/j.1468-2958.2010.01389.x 
Muise, A., Christofides, E., \& Desmarais, S. (2009). More information than you ever wanted: Does Facebook bring out the green-eyed monster of jealousy? Cyberpsychology \& Behavior, 12, 441-444. doi: 10.1089/cpb.2008.0263

Nguyen, M., Bin, Y. S., \& Campbell, A. (2012). Comparing online and offline self-disclosure: A systematic review. Cyberpsychology, Behavior, and Social Networking: 15, 103-111. doi: 10.1089/cyber.2011.0277

Pham, M. N., Shackelford, T. K., \& Sela, Y. (2013). Women's oral sex behaviors and risk of partner infidelity. Personality and Individual Differences, 55, 446-449. doi: 10.1016/i.paid.2013.04.008

Raad, E., Chbeir, R., Dipanda, A. Discovering relationship types between users using profiles and shared photos in a social network. Multimedia Tools and Applications, 64, 141-170. doi: 10.1007/s11042-011-0853-7

Reich, S. M., Subrahmanyam, K., Espinoza, G. (2012). Friending, IMing, and hanging out face-to-face: Overlap in adolescents' online and offline social networks. Developmental Psychology, 48, 356-368. doi: $10.1037 / \mathrm{a} 0026980$

Roney, J. R., Hanson, K. N., Durante, K. M., \& Maestripieri, D. (2006). Reading men's faces: Women's mate attractiveness judgments track men's testosterone and interest in infants. Proceedings of the Royal Society of London B, 273, 2169-2175. doi: 10.1098/rspb.2006.3569

Shackelford, T. K., Goetz, A. T., LaMunyon, C. W., Quintus, B. J., \& Weekes-Shackelford V. A. (2004). Sex differences in sexual psychology produce sex similar preferences for a short-term mate. Archives of Sexual Behavior, 33, 405-412. doi: 10.1023/B:ASEB.0000028893.49140.b6

Schenk, A. M., \& Fremouw, W. J. (2012). Prevalence, psychological impact, and coping of cyberbully victims among college students. Journal of School Violence, 11, 21-37. doi: 10.1080/15388220.2011.630310

Schmitt, D. P., Buss, D. M. (2001). Human mate poaching: Tactics and temptations for infiltrating existing mateships. Journal of Personality and Social Psychology, 80, 894-917. doi: 10.1037/0022-3514.80.6.894

Sell, A., Cosmides, L., Tooby, J., Sznycer, D., Rueden, C., \& Gurven, M. (2009). Human adaptations for the visual assessment of strength and fighting ability from the body and face. Proceedings of the Royal Society of London B, 276, 575-584. doi: 10.1098/rspb.2008.1177

Slonje, R., Smith, P. K., \& Frisen, A. (2013). The nature of cyberbullying, and strategies for prevention. Computers in Human Behavior, 29, 26-32. doi: 10.1016/j.chb.2012.05.024

Starratt, V. G., Goetz, A. T., Shackelford, T. K., Stewart-Williams, S. (2008). Men's partner-directed insults and sexual coercion in intimate relationships. Journal of Family Violence, 23, 315-323. doi: 10.1007/s10896-0089153-z

Stern, L. A., \& Taylor, K. (2007). Social networking on Facebook. Journal of the Communication, Speech, and Theatre Association of North Dakota, 20, 920

Subrahmanyam K, Reich SM, Waechter N, Espinoza G. (2008). Online and offline social networks: Use of social networking sites by emerging adults. Journal of Applied Developmental Psychology, 29, 420-433. doi: 10.1016/j.appdev.2008.07.003

Taraszow, T., Aristodemou, E., Shitta, G., Laouris, Y., \& Arsoy, A. (2010). Disclosure of personal and contact information by young people in social networking sites: An analysis using Facebook TM profiles as an example. International Journal of Media and Cultural Politics, 6, 81-102. doi: dx.doi.org/10.1386/macp.6.1.81/1

Toma, C. L., Hancock, J. T. (Eds.). (2010). Lying for love in the modern age deception in online dating. In: Interplay of Truth and Deception: New Agendas in Communication (pp. 149-164).

Tufekci, Z. (2008). Can you see me now? Audience and disclosure regulation in online social network sites. Bulletin of Science,Technology \& Society, 28, 20-36. doi: 10.1177/0270467607311484

Vaillancourt, T. (2005). Indirect aggression among human: Social construct or evolutionary adaptation? In Tremblay, R. E., Hartup, W. W., Archer, J. (Eds), Developmental Origins of Aggression (pp 158-177). New York: Guilford.

Vaillancourt, T., \& Sharma, A. (2011). Intolerance of sexy peers: Intrasexual competition among women. Aggressive Behavior, 37, 569-77. doi: 10.1002/ab.20413

Valkenburg, P., \& Peter, J. (2007). Preadolescents' and adolescents' online communication and their closeness to friends. Developmental Psychology, 43, 267-277. doi: 10.1037/0012-1649.43.2.267

Wang, S. S., Moon, S. I., Kwon, K. H., Evans, C. A., \& Stefanone, M. A. (2010). Face off: Implications of visual cues on initiating friendship on Facebook. Computers in Human Behavior, 26, 226-234. doi: 10.1016/j.chb.2009.10.001

Young, A. L, \& Quan-Haase, A. (2009). Information revelation and Internet privacy concerns on social network sites: A case study of Facebook. In Proceedings of the4th international conference on communities and technologies (pp. 265-274). NewYork: ACM. doi: 10.1145/1556460.1556499

Yut-Lin, W., \& Othman, S. (2008). Early detection and prevention of domestic violence using the Women Abuse Screening Tool (WAST) in primary health care clinics in Malaysia. Asia Pacific Journal of Public Health, 20, 102-16. doi: 10.1177/1010539507311899

Zakar, R., Zakar, M. Z., Mikolajczyk, R., \& Kraemer, A. (2013). Spousal violence against women and its association with women's mental health in Pakistan. Health Care for Women International, 34, 795-813. doi: 10.1080/07399332.2013.794462

Zhao, S., Grasmuck, S., \& Martin, J. (2008). Identity construction on Facebook: Digital empowerment in anchored relationships. Computers in Human Behavior, 24, 1816-1836. doi: 10.1016/j.chb.2008.02.012

Zweig, J. M., Crockett, L. J., Sayer, A., \& Vicary, J. R. (1999). A longitudinal examination of the consequences of sexual victimization for rural young women. Journal of Sex Research, 36, 396-409. doi: $10.1080 / 00224499909552012$

(Article received: 13-04-2014; revised: 03-12-2014; accepted: 29-12-2014) 